\title{
BIOSYNTHESIS AND AXOPLASMIC TRANSPORT OF NEUROPHYSINS IN THE HYPOTHALAMO-NEUROHYPOPHYSIAL SYSTEM OF RANA PIPIENS
}

\author{
ALICE C. CHANG*,2 AND H. -DIETER DELLMANN $\ddagger$ \\ *Program of Molecular, Cellular and Developmental Biology, and $\ddagger$ Department of Veterinary Anatomy, College of Veterinary \\ Medicine, lowa State University, Ames, lowa 50010
}

Received September 23, 1983; Revised February 9, 1984; Accepted February 10, 1984

\begin{abstract}
Biosynthesis, axoplasmic transport, and storage of neurophysin in the amphibian (Rana pipiens) magnocellular peptidergic neurosecretory system were studied, and the results were compared with those reported in mammals.

After injection of $\left[{ }^{35} \mathrm{~S}\right]$ cysteine into the preoptic recess, light microscopic autoradiography provides evidence that neurons of the preoptic nucleus ( $\mathrm{PON}$ ) synthesize cysteine-rich proteins. The time course of appearance of these $\left[{ }^{35} \mathrm{~S}\right]$ cysteine-labeled proteins in different regions of the hypothalamoneurohypophysial system was studied by slab gel autoradiography. $\left[{ }^{35} \mathrm{~S}\right]$ Cysteine-labeled proteins were found in the PON less than $1 \mathrm{hr}$ postinjection, whereas a major labeled protein, tentatively identified as the neurophysin, first appeared in the infundibulum and neural lobe $4 \mathrm{hr}$ after the injection. In addition, the labeled neurophysin persisted in the neural lobe throughout the entire observation period of 5 days. The minimum transport rate for neurophysin was calculated as 0.9 $\mathrm{mm} / \mathrm{hr}(22 \mathrm{~mm} /$ day $)$ at $25^{\circ} \mathrm{C}$.

Two different neurophysins (with isoelectric points (pI) $4.9 \pm 0.1,4.6 \pm 0.1$, and $M_{\mathrm{r}}=23,000$, $20,100)$ may be resolved from the neural lobe extracts by isoelectric focusing and SDS-polyacrylamide gel electrophoresis, respectively. In addition to the neurophysin peaks, two radioactive peaks with pI 5.2 and 5.8 may be detected in the preoptic nucleus and the infundibulum as early as 30 min after $\left[{ }^{35} \mathrm{~S}\right]$ cysteine injection. Preliminary conversion studies suggest a putative precursor role for the pI 5.2 protein. The results indicate that in the amphibian peptidergic neurosecretory system, the synthesis of cysteine-rich neurophysin by the preoptic neurons, the transport through the infundibulum, and the storage in the neural lobe proceed similarily to their mammalian counterparts.
\end{abstract}

A class of cysteine-rich, low molecular weight (i.e., $10,000$ to 14,000$)$ proteins was first discovered by Van Dyke et al. (1942) in extracts of the bovine pituitary gland. Referred to as the "Van Dyke protein," this protein was found to be complexed with the two peptide hormones, vasopressin and oxytocin. Later, it was isolated and named "neurophysin" by Acher et al. (1955). Much of the work since then has been directed toward the isolation and biochemical characterization of this protein in various species of mammals. There are at least two neurophysins in all of the species examined (with the exception of guinea pig, which has only one), one associated with vasopressin and the other with oxytocin

\footnotetext{
${ }^{1}$ This work was supported by National Institutes of Health Grant 1 RO 1 NS 14062 .

${ }^{2}$ To whom correspondence should be directed at her present address: Department of Neurosciences, National Yang-Ming Medical College, Shih-Pai, Taipei, Taiwan 112, Republic of China.
}

(for review, see Pickering and Jones, 1978; Seif and Robinson, 1978). Vasopressin and oxytocin, together with their respective neurophysins, are synthesized in separate neurons of the supraoptic nucleus (SON) and the paraventricular nucleus (PVN) in the hypothalamus (Vandesande and Dierickx, 1975, 1976a; Vandesande et al., 1975; Aspeslagh et al., 1976).

In the amphibian hypothalamo-neurohypophysial system, vasotocin and mesotocin are produced in separate neurons of the preoptic nucleus (PON) (Acher et al., 1964; Bentley, 1969; Moens, 1972; Acher, 1974; Vandesande and Dierickx, 1976b). The presence of neurophysin, the "carrier protein" of the neuropeptides, in these neurons has been demonstrated indirectly using antibodies against porcine neurophysin II (Watkins, 1975) or bovine neurophysin II (Vandesande and Dierickx, 1976b). This is possible because extensive sequence homology has been revealed in neurophysins isolated from many species (Capra et al., 1972, 1974; Chauvet et al., 
1975, 1976; Wu and Crumm, 1976; Schlesinger et al., 1977; for review, see Pickering and Jones, 1978; Seif and Robinson, 1978). Moens (1974) has isolated a cysteinerich protein fraction from the neural lobe of Rana temporaria and tentatively identified it as neurophysin, with a relatively large molecular wcight of 25,000 . However, no conclusions were drawn as to the number of neurophysins present in the frog neural lobe, because it was uncertain that the fraction was homogeneous.

The biosynthesis and axoplasmic transport of the posterior pituitary hormones and their neurophysins have also been extensively studied in mammals. Sachs and coworkers first hypothesized that vasopressin, oxytocin, and their respective neurophysins are synthesized via common precursors, i.e., prohormones, by neurons of the SON and PVN in the hypothalamus (Sachs and Takabatake, 1964; Sachs et al., 1969). However, candidates for the common precursors were not identified until recently. Gainer and co-workers reported the presence in the rat hypothalamo-neurohypophysial system of two 20,000 -dalton precursors with isoelectric points (pI) of 5.4 and 6.1. Only the pI 5.4 precursor was synthesized in the homozygous Brattleboro rats (with hereditary diabetes insipidus); hence it was identified as the precursor for oxytocin-neurophysin, whereas the pI 6.1 protein was identified as vasopressin-neurophysin precursor (Gainer et al., 1977a, b; Brownstein et al., 1977). Furthermore, Russell et al. (1979, 1980) have isolated the two precursors; by limited proteolysis and affinity chromatography, direct evidence that the two nonapeptides share common precursors with their respective neurophysins has been provided.

Most recently, the biosynthesis of bovine vasopressin and its associated neurophysin via a common precursor has been elegantly demonstrated by the work of Land et al. (1982). The complete amino acid sequence of the precursor as deduced from cDNA prepared from hypothalamic mRNA reveals the intramolecular organization of the precursor (166 amino acids), being composed of a signal sequence, separated by a pair of basic amino acids from vasopressin, which is followed by a glycyl residue and another pair of basic amino acids, and then the neurophysin sequence, and the 17,300-dalton precursor is completed with a glycopolypeptide at the carboxyl terminal.

Since the organelles for protein synthesis appear to be confined to the neuronal perikaryon (Lasek et al., 1974), the biosynthesis of these neuropeptides would necessarily occur at the level of perikaryon; therefore, the axonal transport of these secretory products to the distant terminals in the neural lobe for storage and release is of great functional significance in these peptidergic neurons (Gainer et al., 1977a). The pathway of transport for these neurosecretory products from nuclei in the hypothalamus to the ending in the rat neural lobe has been demonstrated by autoradiography (Sloper, 1966; Nishioka et al., 1970; Kent and Williams, 1974). The transport rate of neurophysin in the rat has been reported to be $120 \mathrm{~mm} /$ day (Gainer et al., 1977b; Brownstein et al., 1980; Fink et al., 1981). In the lower vertebrates, a transport rate of $0.6 \mathrm{~mm} / \mathrm{hr}(14.4 \mathrm{~mm} /$ day $)$ at $21^{\circ} \mathrm{C}$ for isotocin has been reported in the goldfish (Jones et al., 1973).
In the present study, $\left.{ }^{35} \mathrm{~S}\right]$ cysteine-labeled proteins were extracted from the preoptic nucleus, infundibulum, and neural lobe of the frog, Rana pipiens. Analysis by three types of polyacrylamide gel electrophoresis was carried out to determine the number of amphibian neurophysins and the time course of their axonal transport from the preoptic nucleus to the neural lobe. In addition, some preliminary evidence is provided for the existence of precursor proteins of the amphibian neurophysins.

\section{Materials and Methods}

Animals and operative procedures. Male or female frogs (R. pipiens) were anesthetized by immersion in $0.1 \%$ Finquel solution. Following paraoral exposure of the ventral brain surface rostral to the optic chiasma, $3 \mu \mathrm{l}$ of frog Ringer solution ( $2 \mathrm{~mm}$ HEPES buffer, $\mathrm{pH} 7.4,114$ $\mathrm{mM} \mathrm{NaCl}, 2 \mathrm{mM} \mathrm{KCl}$, and $\left.1.8 \mathrm{mM} \mathrm{CaCl}_{2}\right)($ Hammerschlag et al., 1975) containing $6 \mu \mathrm{Ci}$ of $\left[{ }^{35} \mathrm{~S}\right]$ cysteine (specific activity $300 \mathrm{Ci} / \mathrm{mmol}$, New England Nuclear) and $10 \mathrm{~mm}$ dithiothreitol (DTT) were injected into the preoptic recess over a period of $5 \mathrm{~min}$. The needle remained in position for $10 \mathrm{~min}$ before removal. Animals usually regain consciousness 15 to 20 min later. At selected time intervals postinjection, groups of five animals were killed, and pooled samples of preoptic areas, infundibula, and neural lobes were homogenized in $0.1 \mathrm{~N} \mathrm{HCl}$ and kept at $4^{\circ} \mathrm{C}$ for $18 \mathrm{hr}$ (Dean et al., 1967) before being stored at $-70^{\circ} \mathrm{C}$.

Polyacrylamide gel electrophoresis of labeled proteins. The three types of polyacrylamide gel electrophoresis (PAGE) used to separate $\left[{ }^{35} \mathrm{~S}\right]$ cysteine-labeled proteins from the isolated tissues are: basic $\mathrm{pH}$ gels (Davis, 1964), sodium dodecyl sulfate (SDS) gels (Laemmli, 1970; Takaćs, 1979), and isoelectric focusing (IEF) gels (O'Farrell, 1975). To prepare tissue samples for gel electrophoresis, the frozen acid extracts were thawed and centrifuged at $2400 \times g$. The supernatant was treated with $10 \%$ trichloroacetic acid (TCA), and the precipitated proteins were separated from the TCA-soluble fraction by centrifugation. The TCA precipitants were washed with ether (Gainer et al., 1977a) and redissolved in sample buffer appropriate for the gel system to be used. For visualization of the protein bands, the gels were stained with $0.25 \%$ Coomassie brilliant blue R-250 in 9\% acetic acid and $45 \%$ methanol and destained in $7 \%$ acetic acid.

Analysis of radioactivity. Polyacrylamide tube gels were sliced into 2-mm thick discs. Each disc was put into a scintillation vial, to which $0.5 \mathrm{ml}$ of Protosol (New England Nuclear) was added, and was incubated at $37^{\circ} \mathrm{C}$ overnight. 'Ten milliliters of Econofluor (New England Nuclear) were added to each vial the next day before counting in a Tricarb liquid scintillation spectrometer (model 2425, Packard). Counting efficiency was estimated to be $38 \%$ with less than $20 \mathrm{cpm}$ background. Slab gels were dried onto $3 \mathrm{MM}$ Whatman paper $(5 \times 7)$, contacted with Kodak X-Omat film (XR-5), and exposed at $-70^{\circ} \mathrm{C}$ for 10 to 20 days before processing in an automated x-ray film processor. Fluorography was carried uut according to the procedure of Bonner and Laskey (1974).

Light microscopy and autoradiography. The preoptic area was dissected out and fixed in $5 \%$ glutaraldehyde in 
$0.1 \mathrm{M}$ phosphate buffer ( $\mathrm{pH} 7.4)$, postfixed in $1 \% \mathrm{OsO}_{4}$ in $0.03 \mathrm{M}$ veronal acetate buffer $(\mathrm{pH} 7.4)$, dehydrated through graded alcohol and acetone, and embedded in an Epon-Araldite mixture. Serial cross-sections $(3 \mu \mathrm{m})$ were cut and stained with Gomori's aldehyde fuchsin method using a modified procedure of Coates and Teh (1978). $\left[{ }^{35} \mathrm{~S}\right]$ Cysteine $(6 \mu \mathrm{Ci} /$ frog) was injected into the preoptic recess, and the animals were killed at 2,4 , and $6 \mathrm{hr}$ and 1,3 , and 7 days postinjection. The preoptic area and neural lobe were fixed and processed as described above. Serial cross-sections or sagittal sections $(3 \mu \mathrm{m})$ mounted on slides were dipped in Kodak nuclear track emulsion (NTB-2) diluted with distilled water (v/v: $22 / 17)$ at $37^{\circ} \mathrm{C}$. The emulsion-coated slides were allowed to dry at $37^{\circ} \mathrm{C}$ and $90 \%$ relative humidity for $30 \mathrm{~min}$, then at $29^{\circ} \mathrm{C}$ and $90 \%$ relative humidity for $2 \mathrm{hr}$ before being sealed in slide boxes containing Drierite and exposed at $-70^{\circ} \mathrm{C}$ for 4 to 6 weeks. At the end of exposure, the slides were developed in D-19 developer for $2 \mathrm{~min}$, rinsed in distilled water for $10 \mathrm{sec}$, fixed in Kodak fixer for $5 \mathrm{~min}$ at $17^{\circ} \mathrm{C}$, rinsed in running tap water for $30 \mathrm{~min}$, further rinsed in distilled water, and air dried.

\section{Results}

The Gomori-positive neurosecretory cell bodies of the preoptic nucleus (PON) are found in the medioventral and laterodorsal region of the hypothalamus. Specifically labeled neurons are found in these areas in animals killed $2 \mathrm{hr}$ after the injection of $\left[{ }^{35} \mathrm{~S}\right]$ cysteine into the preoptic recess (Fig. 1). No significant label is found in the ependymal cells lining the third ventricle and preoptic recess. Labeled neurosecretory cells are present in animals killed at 4 and $6 \mathrm{hr}$; however, they are not as heavily labeled as at $2 \mathrm{hr}$. One day or longer after the isotope injection, the labeling is insufficient to allow a clear differentiation of these cells from the background.

Incorporation of $\left[{ }^{35} S\right]$ cysteine into the neurohypophysial proteins and their axonal transport into the neural lobe. The time course of appearance of $\left[{ }^{35} \mathrm{~S}\right]$ cysteinelabeled proteins in the hypothalamo-neurohypophysial system was studied by basic $\mathrm{pH}$ gel electrophoresis $(7 \%)$ and autoradiography. The Coomassie blue staining patterns of proteins extracted from PON (Fig. 2A), infundibulum (Fig. $2 C$ ), or neural lobe (Fig. $2 E$ ) are similar throughout all time points examined. While many proteins are present in the PON and infundibulum, the protein profiles of the neural lobe are relatively simple. In addition to several minor bands with relatively slower mobilities, one major band with fast mobility $(R f=0.81)$ is found in the neural lobe. A protein band with the same mobility is also present in the PON and infundibulum, and we thus designate this protein as $\mathrm{Np}$ protein.

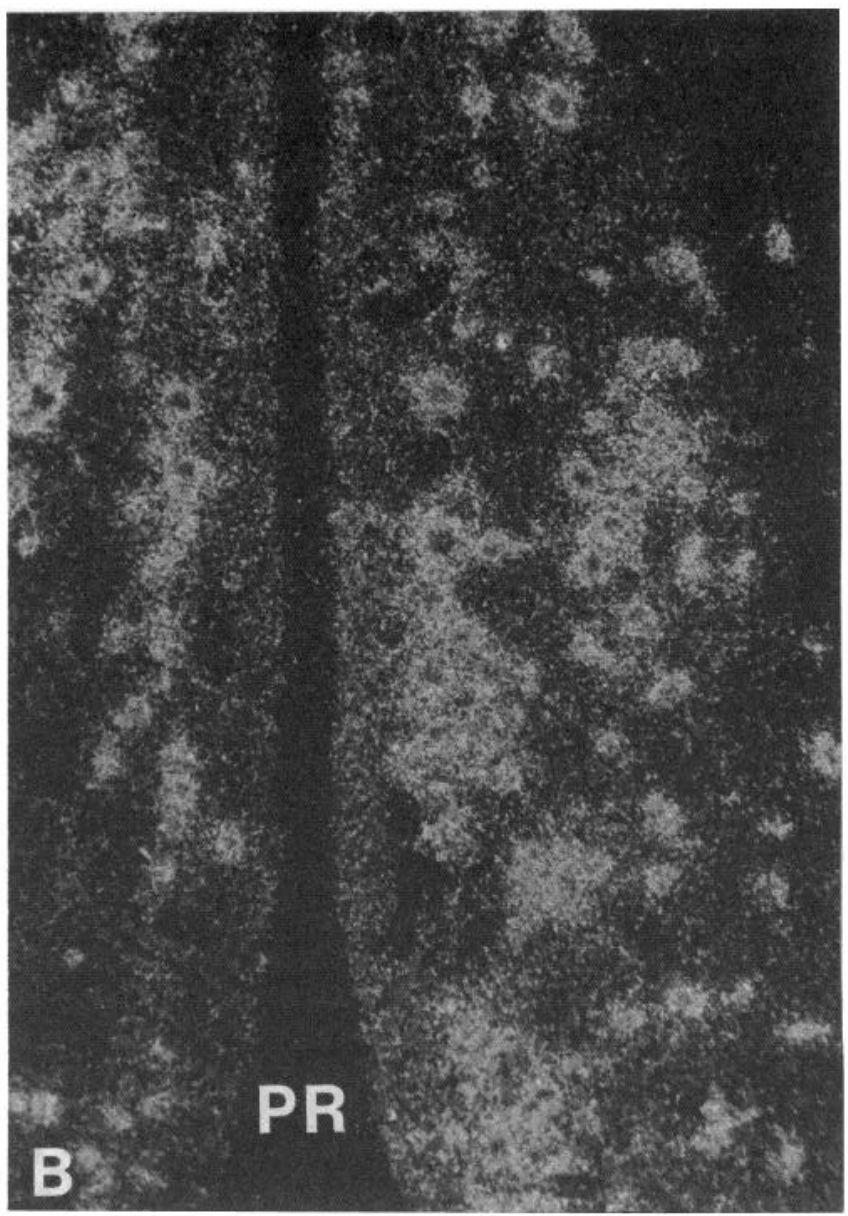

Figure 1. A, Transverse section of the preoptic area showing labeled cells in the medioventral region of the PON. $P R$, preoptic recess; brightfield. Magnification $\times 95$. $B$, Darkfield micrograph of an adjacent section. Note that the nucleus of the PON cells and the ependymal cells lining the preoptic recess are not significantly labeled. $P R$, preoptic recess. Magnification $\times 298$. 

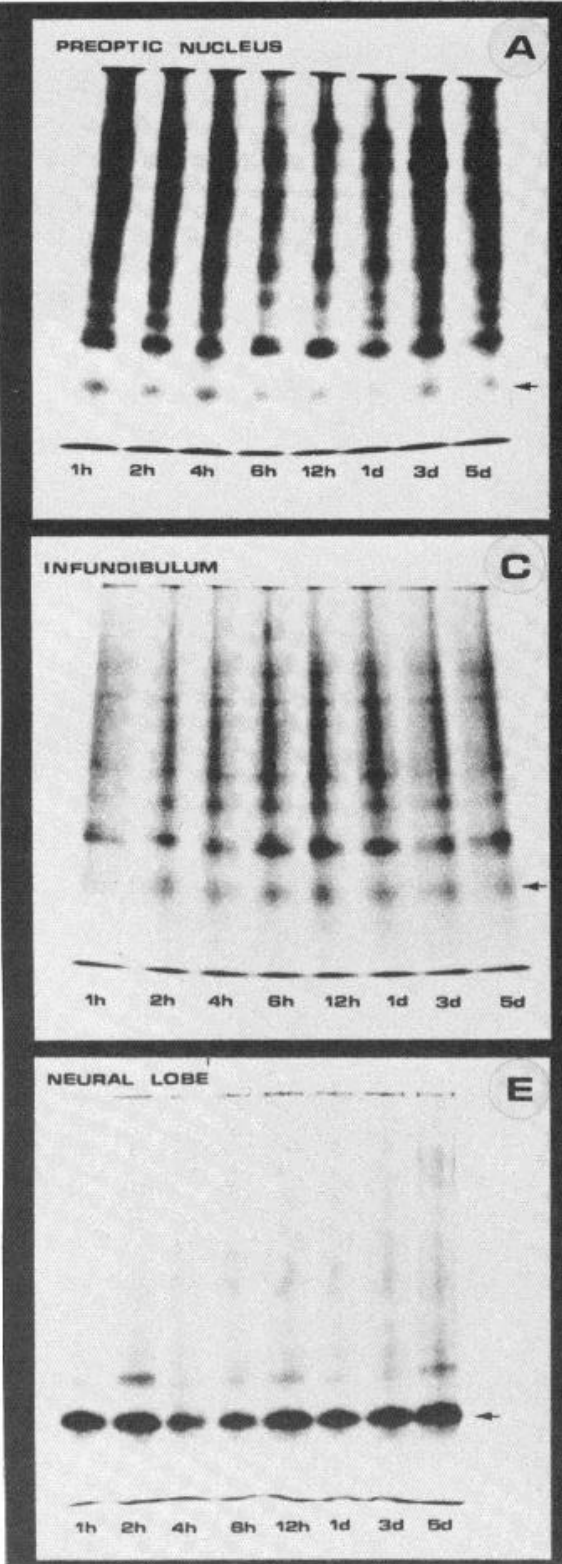

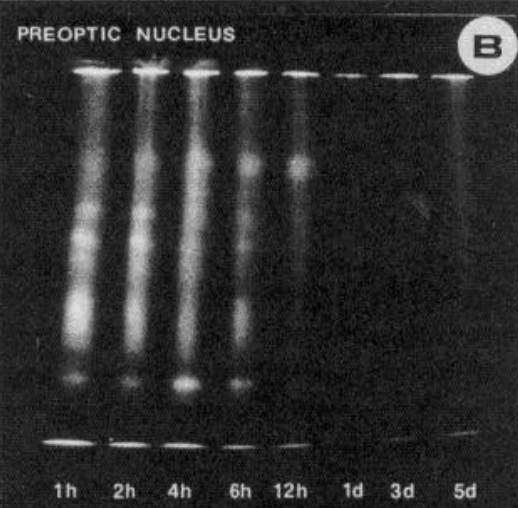

INFUNDIBULUM

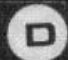

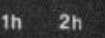

NEURAL LOBE
Figure 2. Polyacrylamide slab gel electrophoresis in a basic $\mathrm{pH}$ system of $\left[{ }^{35} \mathrm{~S}\right]$ cysteine-labeled proteins extracted from various regions of the hypothalamo-neurohypophysial system of the frog at selected times after injection of $\left.{ }^{35} \mathrm{~S}\right]$ cysteine into the preoptic recess. $A, C$, and $E$ are the Coomassie blue-stained protein banding patterns of the preoptic nucleus, infundibulum, and neural lobe. $B, D$, and $F$ are the respective autoradiograms of the three stained slabs to reveal the time course of appearance of labeled proteins in the above three areas. The arrow indicates the position migrated by the $\mathrm{Np}$ protein.
In the respective slab gel autoradiogram of the PON (Fig. $2 B$ ), at least five labeled protein bands, including the $\mathrm{Np}$ band, are present as early as $1 \mathrm{hr}$ after the injection. The labeled bands decrease in intensity with time and are no longer detectable after $24 \mathrm{hr}$. In the infundibulum (Fig. $2 D$ ), the $\mathrm{Np}$ band is clearly labeled by $4 \mathrm{hr}$, persists through $12 \mathrm{hr}$, and is no longer detectable $24 \mathrm{hr}$ after the injection. On the contrary, in the respective autoradiogram of the neural lobe (Fig. $2 F$ ), no labeled proteins are present at 1 and $2 \mathrm{hr}$ after the injection. The labeled $\mathrm{Np}$ band first appears at $4 \mathrm{hr}$ and persists throughout the entire observation period of 5 days. A faint band $(R f=0.66)$ is also labeled. Thus, the results indicate that it takes at the most $4 \mathrm{hr}$ for $\left.{ }^{35} \mathrm{~S}\right]$ cysteine to be incorporated into the $\mathrm{Np}$ protein and transported to the neural lobe. Since the average length of the hypothalamo-neurohypophysial tract of the frog is $3.6 \mathrm{~mm}$, the minimum rate of transport is $0.9 \mathrm{~mm} / \mathrm{hr}$ $(22 \mathrm{~mm} /$ day $)$ at $25^{\circ} \mathrm{C}$.
Evidence that the labeled proteins are synthesized by neurons of the PON and not by the pituicytes in the neural lobe is also provided. Five days after the injection of isotope, the radioactivity of the neural lobe (total tissue homogenate) represents $3 \%$ of that in the PON region. It increases to $5.6 \%$ in animals stimulated by salt loading for 7 days, whereas in animals with transected stalk, the radioactivity in the neural lobe is only $0.1 \%$ of that in the PON (Table I). Light microscopic autoradiography also shows that 3 days after the isotope injection, the median eminence and neural lobe of control animals are heavily labeled, whereas in animals microiontophoretically injected with vinblastine at the level of median eminence, the neural lobe is free of any significant amount of labels (Chang and Dellmann, 1983).

Analysis of proteins transported to the neural lobe. For further analysis of the labeled proteins transported to the neural lobe, the acid-extracted, TCA-precipitated proteins were separated by three different PAGE sys- 
TABLE I

Total tissue homogenate collected from various regions of the hypothalamo-neurohypophysial system were counted 5 days after the injection of $\left[{ }^{35} \mathrm{~S}\right]$ cysteine $(5 \mu \mathrm{Ci} / \mathrm{frog})$ into the preoptic recess

\begin{tabular}{|c|c|c|c|c|}
\hline & PON & $\begin{array}{l}\text { Median } \\
\text { Eminence }\end{array}$ & $\begin{array}{l}\text { Neural } \\
\text { Lobe }\end{array}$ & Total Counts \\
\hline \multicolumn{5}{|l|}{ A. Control animals ${ }^{a}$} \\
\hline Counts per minute & 73,320 & 47,590 & 2,310 & 123,220 \\
\hline Percentage of total & $60 \%$ & $30 \%$ & $2 \%$ & \\
\hline Percentage of PON & & $64 \%$ & $3 \%$ & \\
\hline \multicolumn{5}{|c|}{ B. Animals salt-loaded with $1 \% \mathrm{NaCl}$ for 7 days before injection } \\
\hline Counts per minute & 50,480 & 36,210 & 2,860 & 89,550 \\
\hline Percentage of total & $56 \%$ & $41 \%$ & $3.2 \%$ & \\
\hline Percentage of PON & & $71 \%$ & $5.6 \%$ & \\
\hline \multicolumn{5}{|c|}{$\begin{array}{l}\text { C. Animals with median eminence transected at the time of isotope } \\
\text { injection }\end{array}$} \\
\hline Counts per minute & 54,580 & 40,010 & 90 & 94,580 \\
\hline Percentage of total & $58 \%$ & $42 \%$ & $0.1 \%$ & \\
\hline Percentage of PON & & $71 \%$ & $0.1 \%$ & \\
\hline
\end{tabular}

${ }^{a}$ Data obtained by pool of three animals treated alike.

tems. Figure $3 A$ shows the pattern of labeled proteins on the basic $\mathrm{pH}$ gel (10\%, pH 9.5). One major peak of radioactivity was detected. However, separation of the labeled neural lobe proteins on IEF-PAGE revealed two labeled proteins with pI $4.6 \pm 0.1$ and $4.9 \pm 0.1$ (Fig. $3 B$ ). In addition, two labeled proteins may also be resolved by SDS-PAGE either in tube gel (12.5\%) (Fig. $3 \mathrm{C}$ ) or in slab gel $(10 \%)$ (Fig. $3 D)$. The estimated molecular wcights are 23,000 and 20,100, respectively.

Biosynthesis of $\left[{ }^{35} S\right]$ cysteine-labeled proteins in the hypothalamo-neurohypophysial system. The labeling profiles of proteins synthesized in the PON, transported through the infundibulum, and stored in the neural lobe were analyzed by IEF-PAGE at various times after the injection of $\left[{ }^{35} \mathrm{~S}\right]$ cysteine into the preoptic recess. As shown in Figure $4 A$, the PON labeling profile 30 min after the injection is dominated by a peak of radioactivity with $\mathrm{pI}$ 5.2. Much less label is present in the range of 4.3 to 4.9 and 5.8 to 6.0 . As a function of time, the radioactivity associated with the pI 5.2 peak gradually decreases relative to that associated with the peaks having $\mathrm{pI}$ values ranging from 4.3 to 4.9 . By $6 \mathrm{hr}$, an approximately equal amount of label is present in peaks with pI 5.2, 4.9, and 4.6. Furthermore, the total radioactivity in the PON is also decreasing with time; by $24 \mathrm{hr}$, only trace amounts of the pI 5.2 peak are present. In the infundibulum (Fig. $4 B$ ), at $30 \mathrm{~min}$ the radioactivity is present in peaks with pIs $5.2,4.3$ to 4.9 , and 5.8 to 6.0 . However, the peaks with pI 5.8 to 6.0 are clearly present in this region at 4 and $6 \mathrm{hr}$ after the injection. With time, the relative amount of radioactivity present in peaks with $\mathrm{pI}$ ranging from 4.6 to 4.9 increases when compared to that in the pI 5.2 peak. In the neural lobe (Fig. $4 C$ ), no labeled peaks can be detected by the present method until $24 \mathrm{hr}$ after the injection. Using an expanded $\mathrm{pH}$ gradient $(\mathrm{pH} 4$ to 6 ), two peaks of radioactivity may be consistently resolved with pI $4.6 \pm 0.1$ and pI $4.9 \pm 0.1$. No labeled proteins with pI 5.8 to 6.0 or pI 5.2 were detected at any time points examined in the neural lobe.

\section{Discussion}

The magnocellular neurosecretory cells of $R$. pipiens may be specifically labeled by $\left[{ }^{35} \mathrm{~S}\right]$ cysteine after a short pulse. This is the first direct evidence that these cells synthesize cysteine-rich proteins. The distribution of these neurons in the PON is comparable to that illustrated in other amphibia by the immunocytochemical staining method, using antibodies against porcine neurophysin II (Watkins, 1975) or bovine neurophysin II (Vandesande and Dierickx, 1976b).

The initial evidence that newly synthesized and thus labeled proteins are transported from the perikarya in the PON to axon terminals in the neural lobe comes from the results of light microscopic autoradiography. The PON cells can be specifically labeled and clearly identified only after a short pulse, i.e., $2 \mathrm{hr}$, but not after a pulse longer than $6 \mathrm{hr}$. The neural lobe, on the contrary, is not significantly labeled until $24 \mathrm{hr}$ after the isotope injection, and the label persists in the neural lobe for as long as 7 days (data not shown). Considering the halflife of (1) 13 days for vasopressin and oxytocin, (2) 19.8 days for vasopressin-neurophysin, and (3) 13.3 days for oxytocin-neurophysin (Sachs et al., 1969; Jones and Pickering, 1972; Burford and Pickering, 1973; Pickering et al., 1975), it is unlikely that the diminishing labeling intensity in the PON neurons is entirely due to turnover. Furthermore, the above results correlate with that of the time course study, in which labeled proteins extracted from PON, infundibulum, and neural lobe were separated by PAGE. The resulting slab gel autoradiogram of the PON suggests that incorporation of $\left[{ }^{35} \mathrm{~S}\right]$ cysteine into proteins, including the $\mathrm{Np}$ band, is rapid and approximates a pulse incubation, since no labeled proteins were detectable by $24 \mathrm{hr}$ after the injection. In addition, the transient appearance of these labeled proteins, particularly the $\mathrm{Np}$ band, in the infundibulum and the persistant existence of this labeled protein band in the neural lobe from $4 \mathrm{hr}$ through 5 days all imply that this $\mathrm{Np}$ protein is synthesized first in the PON and then transported intra-axonally to the neural lobe for storage via axons transversing the infundibulum. The fact that no significant amount of labels can be detected in the neural lobe of animals with their hypothalamo-neurohypophysial tract either transected or treated with vinblastine (Chang and Dellmann, 1983) lends further support that the labeled $\mathrm{Np}$ protein detected in the neural lobe is coming from the neural cell bodies in PON rather than from de novo synthesis by the pituicytes. This is consistent with reports on other mammalian species (Sachs, 1960; Sachs and Takabatake, 1964; Takabatake and Sachs, 1964; Sachs et al., 1969). Since Np protein is the only major protein present in the neural lobe, rich in cysteine, and originated from PON, it is tentatively identified as the neurophysin protein of $R$. pipiens.

The estimated minimum transport rate of $22 \mathrm{~mm} /$ day at $25^{\circ} \mathrm{C}$ for the newly synthesized neurophysin is similar to that reported for isotocin in the goldfish, i.e., $24 \mathrm{~mm} /$ day at $21^{\circ} \mathrm{C}$ (Jones et al., 1973). We have not studied the effect of temperature on rate of transport. However, the $Q_{10}$ values for axoplasmic transport in nerve preparations of various mammalian and nonmammalian species have 
A. BASIC-PAGE(10\%)

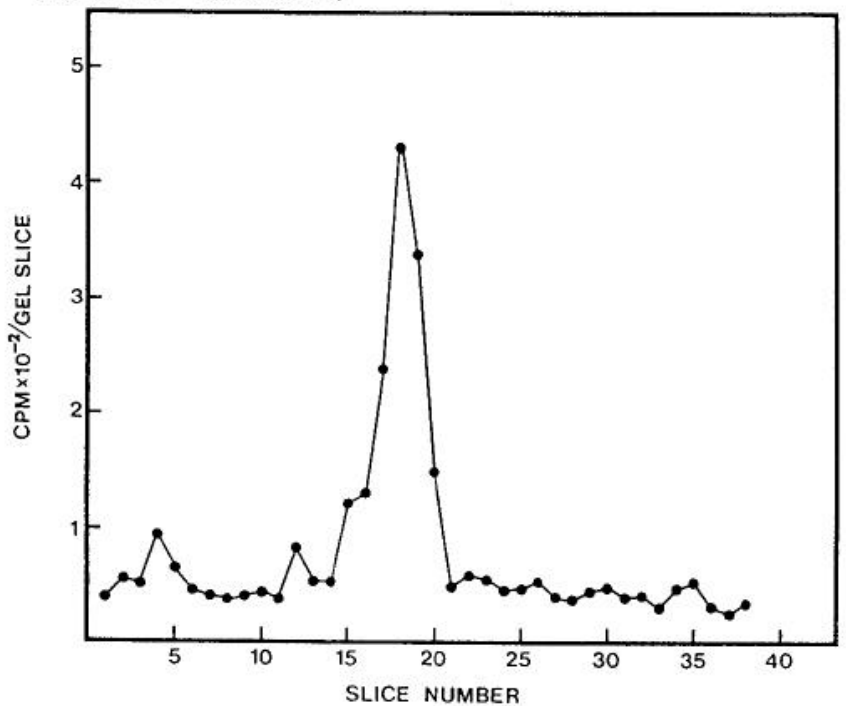

C. SDS-PAGE (12.5\%)

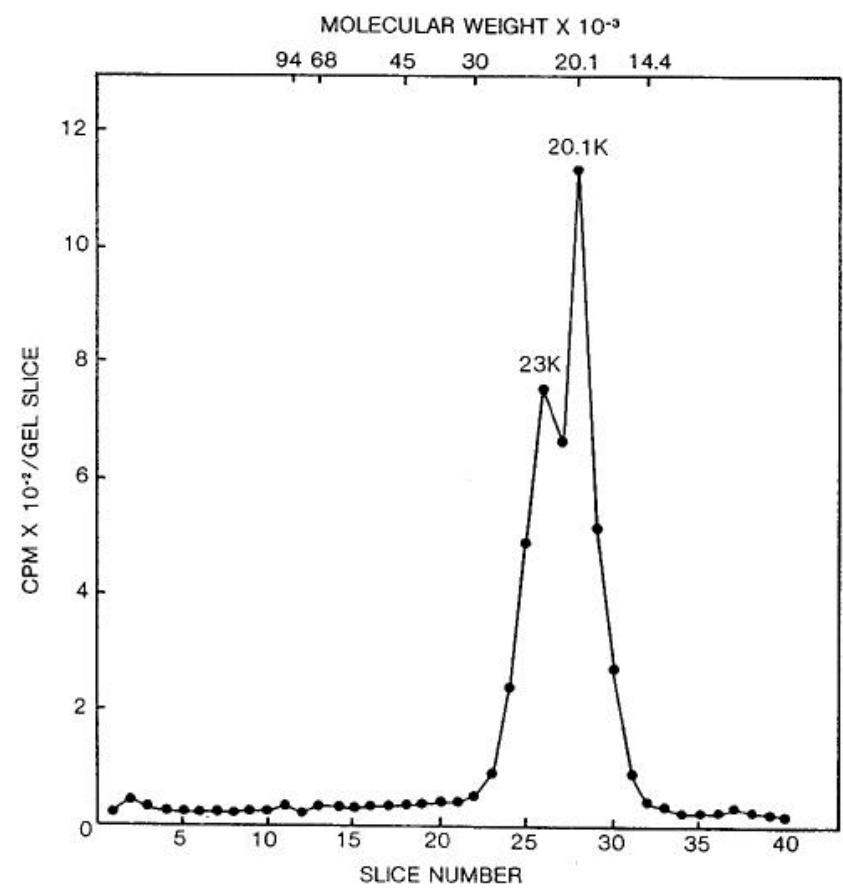

B. IEF - PAGE

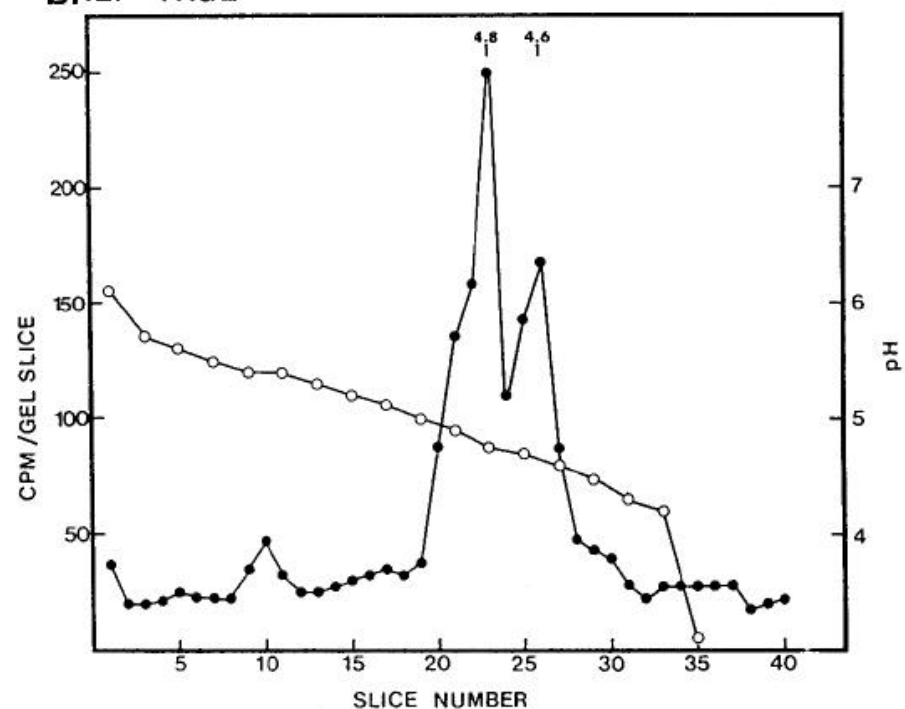

D

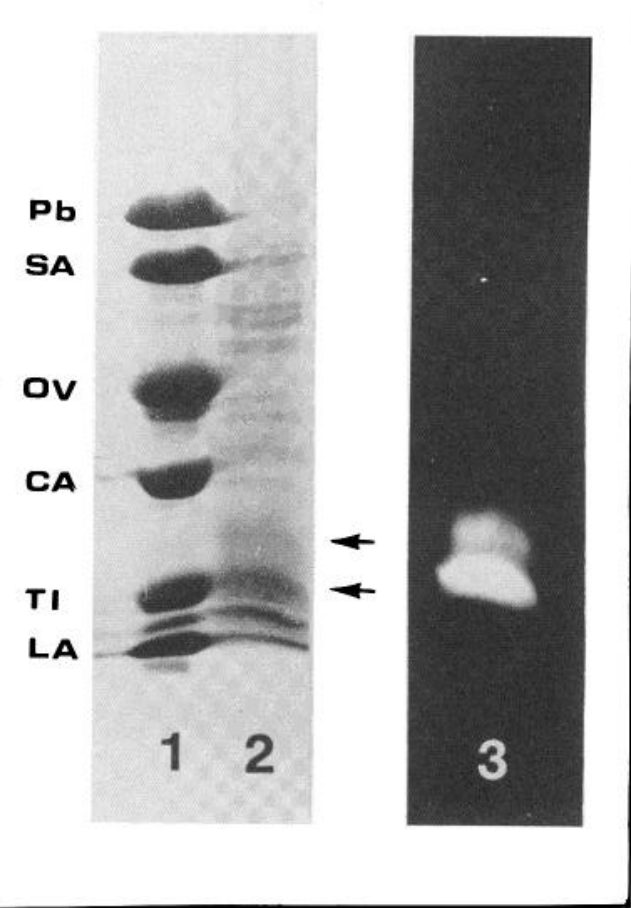

Figure 3. Characterization of $\left[{ }^{35} \mathrm{~S}\right]$ cysteine-labeled proteins transported to the neural lobe by three types of PAGE. A, Basic $\mathrm{pH}$ gel $(10 \%, \mathrm{pH} 9.5)$. B, IEF-PAGE (pH 4 to 6$)$. The line of open circles denotes pH gradient measured in a co-run gel. $C$, SDSPAGE (12.5\%). Upper abscissa shows the slice positions of marker proteins of known molecular weight in a co-run gel. $D$, Slab SDS-PAGE (10\%) fluorography. Tracks 1 and 2, Coomassie blue staining pattern of molecular weight standards and labeled proteins extracted from neural lobe, respectively. Track 3, The corresponding fluorogram of track 2 . $P b$, phosphorylase b (94,000); $S A$, serum albumin $(68,000) ; O V$, ovalbumin $(43,000)$; $C A$, carbonic anhydrase $(30,000)$; $T I$, trypsin inhibitor $(20,100) ; L A, \alpha-$ lactoalbumin $(14,400)$.

been determined to range from 2 to 3.5 (Ochs, 1982). If $\mathrm{Q}_{10}$ of the amphibian hypothalamo-neurohypophysial system is sufficiently high, the extrapolated transport rate at $38^{\circ} \mathrm{C}$ may approximate the 120 to $140 \mathrm{~mm} /$ day rate reported for rat neurophysin (Fink et al., 1981).

Resolution of the labeled proteins transported to the neural lobe was apparently not feasible using the basic $\mathrm{pH}$ gel system (Fig. $3 A$ ). However, two peaks of radio- activity were resolved by both IEF-PAGE (Fig. $3 B$ ) and SDS-PAGE (Fig. 3, $C$ and $D$ ). These data support the conclusion derived from immunocytochemical studies (Vandesande and Dierickx, 1976b) that two different neurophysins are present in the amphibian hypothalamo-neurohypophysial system. Also, in both SDS and IEF gels, the amounts of labels associated with the two neurophysins are apparently not equal; this may be due 


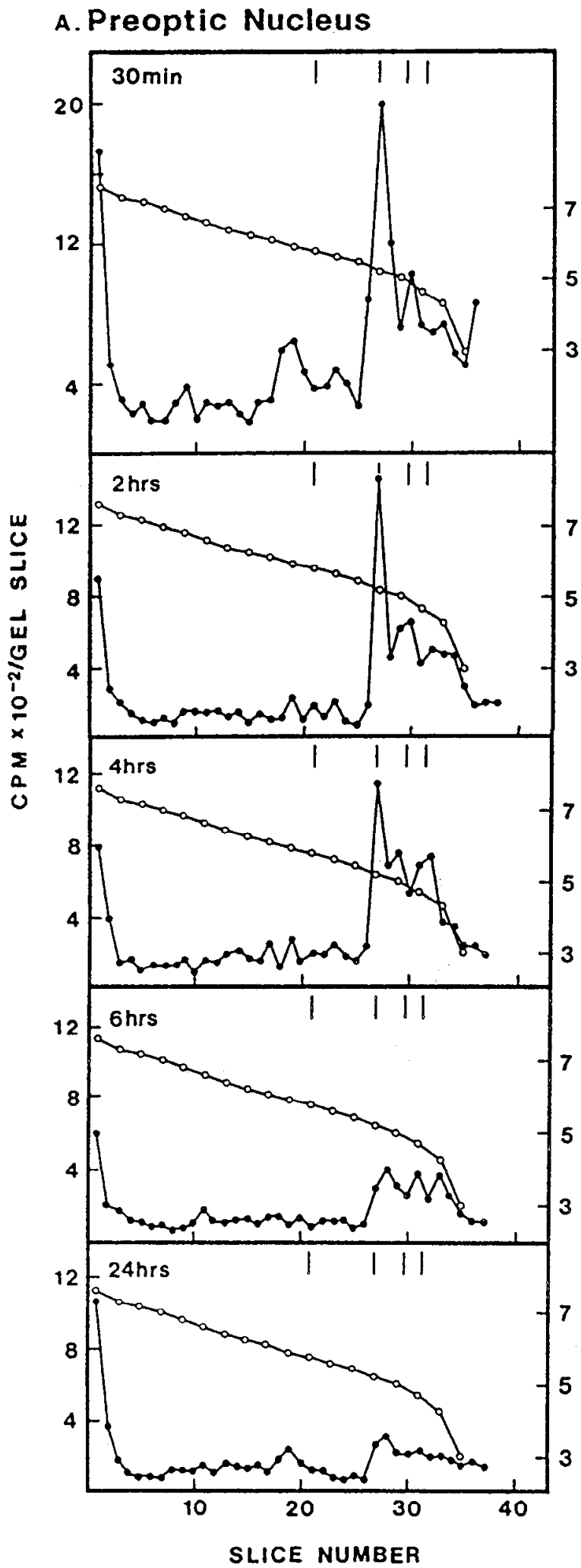

\section{B. Infundibulum}
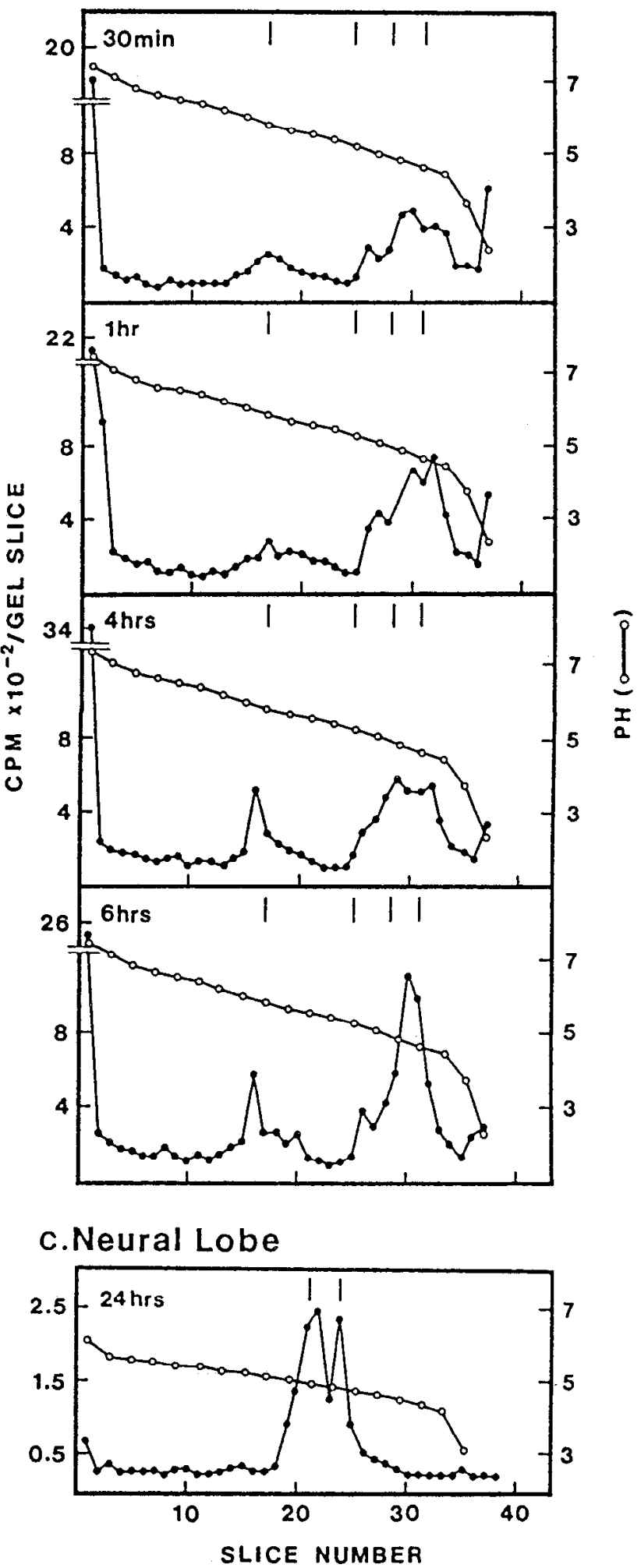

Figure 4. IEF-PAGE of labeled proteins extracted from three areas of the hypothalamo-neurohypophysial system at various times after injection of $\left[{ }^{35} \mathrm{~S}\right]$ cysteine into the preoptic recess. $A$, Preoptic nucleus (pH 3.5 to 10 ); the markings denote the positions on gel with pIs $5.8,5.2,4.9$, and 4.6. $B$, Infundibulum (pH 3.5 to 10); the markings denote the positions on gel with pIs $5.8,5.2,4.9$, and 4.6. $C$, Neural lobe ( $\mathrm{pH} 4$ to 6 ); the markings denote the pIs of the two radioactive peaks. 
to differences in synthesis, release, or the number of cells responsible for production of these two proteins. Whether a constant ratio exists, as was found in the rat between vasopressin-neurophysin and oxytocin-neurophysin (Burford et al., 1971), remains to be determined. Equally important is the identification of the respective peptide hormones, i.e., vasotocin and mesotocin, with which these two neurophysins are associated in vivo.

The pI values of these two cysteine-rich proteins (i.e., $4.6 \pm 0.1$ and $4.9 \pm 0.1$ ) confirm that they are acidic in nature. Also the pIs are similar to those of vasopressinassociated (4.8) and oxytocin-associated (4.6) neurophysin of the rat (Brownstein and Gainer, 1977; Gainer et al., 1977a).

The molecular weights of the two neurophysins (i.e., 23,000 and 20,000) are both smaller than the 25,000 reported for neurophysin of $R$. temporaria (Moens, 1974). Yet, both are larger than all the known mammalian neurophysins (i.e., 10,000 to 14,000) (Pickering and Jones, 1978). Molecular weights of the chicken neurophysins (both may be in dimeric form) were reported to be about 50,000 and 31,000 (Peek and Watkins, 1977). The significance of neurophysins with larger molecular weights in lower vertebrates is not clear at this time. However, Sawyer (1961) has hypothesized that a gene duplication of the Arg-vasotocin sequence has occurred between the appearance of the most primitive lamprey and the cartiliginous fishes. While Arg-vasotocin remains unchanged and is present throughout the vertebrate phyla, except mammals, the other gene had undergone point mutations, thus giving rise to genes of the oxytocin family. A similar mechanism has also been implicated for the neurophysins, since intraspecies sequence homology between mammalian vasopressin-neurophysin and oxytocin-neurophysin may be as high as 80\% (Pickering and Jones, 1978). Our present data indicate that the amphibian neurophysins, presumably the vasotocin-neurophysin and the mesotocin-neurophysin, are approximately twice as large as their mammalian counterparts. This implies a more complex evolutionary process for the two neurophysins in the more advanced vertebrates (i.e., it would involve a deletion of about $50 \%$ of the neurophysin genome). It will be interesting to find out what has been encoded in this "extra" sequence of the lower vertebrates. The examination of the chemical structures by comparing amino acid sequences between amphibian and mammalian neurophysins is necessary to lend insight to this issue.

A pulse label paradigm has been used to study the biosynthesis of the frog neurophysin. One of the essential steps in the identification of a precursor protein is to be able to detect that, during the pulse, a labeled protein with larger molecular weight (precursor) is first synthesized, and then decreased with time as the lower molecular weight polypeptide (product) is formed (Gainer et al., 1977c). IEF-PAGE with a broad $\mathrm{pH}$ gradient of 3.5 to 10 was used to detect if any $\left[{ }^{35} \mathrm{~S}\right]$ cysteine-labeled proteins exist preceding the appearance of the neural lobe peaks. The results indicate that there are, in addition to peaks with pI range similar to that of the neurophysins, two peaks with pI 5.2 and 5.8 in the PON shortly after isotope injection. The pI 5.8 peak is not detectable after $1 \mathrm{hr}$. However, the pI 5.2 peak remains a prominent peak and decreases in radioactivity with time relative to that in the pI 4.9 and 4.6 peaks. 'I'he neural lobe peak never attains the amount of radioactivity as expected from a simple conversion in the perikarya since after 4 $\mathrm{hr}$ the total radioactivity present in the PON also decreases with time; by $24 \mathrm{hr}$, only trace amounts of pI 5.2 can be detected. This suggests that an "intragranular maturation" process is taking place during axonal transport, as has been proposed for neurophysin in the mammalian systems (Sachs et al., 1969; Pickering et al., 1975; Gainer et al., 1977a). Evidence for axonal transport is also revealed by the presence of pI 5.8 and 5.2 peaks in the infundibulum at $30 \mathrm{~min}$ and $1 \mathrm{hr}$. A similar decrease in radioactivity of the pI 5.2 peak and the concomitant increase in peaks with pIs ranging from 4.6 to 4.9 is also seen from 1 through $6 \mathrm{hr}$. However, the change associated with the pI 5.8 peak as a function of time is not the same as the pI 5.2 peak. These data suggest that the pI 5.2 protein is more likely to be the putative precursor for neurophysins. No labeled proteins with pI 5.8 or 5.2 can be detected at any time points examined in the neural lobe. Either it is a matter of sensitivity of the method, or perhaps the processing of the putative precursor protein may have been completed by the time the NGVs arrive at the neural lobe. The above results are preliminary in the identification of precursor protein for the frog neurophysins, since it would be necessary to demonstrate that the pI 5.2 protein has a higher molecular weight than the two neurophysins. Also, the unequivocal proof for the precursor identification requires the isolation of these molecules for further immunological, peptide mapping, and amino acid sequencing studies.

\section{References}

Acher, R. (1974) Chemistry of the neurohypophysial hormones: An example of molecular evolution. In Handbook of Physiology. Sect. 7: Endocrinology, R. 0. Greep and E. B. Astwood, eds., pp. 119-130, American Physiology Society, Washington, D.C.

Acher, R., G. Manoussoss, and G. Olivery (1955) Sur les relations entre locytocine et la vasopressine d'une part et la protein de van Dyke d'autre part. Biochim. Biophys. Acta 16: $155-156$.

Acher, R., R. Beaupain, J. Chauvet, M. T. Chauvet, and D. Crepy (1964) The neurohypophysial hormones of the amphibians. Comparison of the hormones of Rana esculanta and Xenopus laevis. Gen. Comp. Endocrinol. 4: 596-601.

Aspeslagh, M. -R., F. Vandesande, and K. Dierickx (1976) Electron microscopic immunocytochemical demonstration of separate neurophysin vasopressinergic and neurophysin oxytocinergic nerve fibers in the neural lobe of the rat hypophysis. Cell Tissue Res. 171: 31-37.

Bentley, P. J. (1969) Neurohypophysial hormones in amphibian, a comparison of their action and storage. Gen. Comp. Endocrinol. 13: 39-44.

Bonner, W. M., and R. A. Laskey (1974) A film detection method for ${ }^{3} \mathrm{H}$-labeled proteins and nucleic acids in polyacrylamide gels. Eur. J. Biochem. 46: 83-88.

Brownstein, M. J., and H. Gainer (1977) Neurophysin biosynthesis in normal rats and rats with hereditary Diabetes Insipidus. Proc. Natl. Acad. Sci. U. S. A. 74: 4046-4049. 
Brownstein, M. J., A. G. Robinson, and H. Gainer (1977) Immunological identification of rat neurophysin precursors. Nature 269: 259-261.

Brownstein, M. J., J. T. Russell, and H. Gainer (1980) Synthesis, transport and release of posterior pituitary hormones. Science 207: 373-378.

Burford, G. D., and B. T. Pickering (1973) Intraaxonal transport and turnover of neurophysin in the rat. A proposal for a possible origin of the minor component neurophysin. Biochem. J. 136: 1047-1052.

Burford, G. D., C. W. Jones, and B. T. Pickering (1971) Tentative identification of a vasopressin-neurophysin and an oxytocin-neurophysin in the rat. Biochem. J. 124: 809813.

Capra, J., J. Kehoe, D. Kotelchuck, R. Walter, and E. Breslow (1972) Evolution of neurophysin proteins: The partial sequence of bovine neurophysin I. Proc. Natl. Acad. Sci. U. S. A. 69 : 431-434.

Capra, J., K. Cheng, H. Friesen, W. North, and R. Walter (1974) Evolution of neurophysin proteins: The partial sequence of human neurophysin-L. FEBS Lett. 46: 71-74.

Chang, A. C., and H. -D. Dellmann (1983) A fine structural study of the formation of temporary swellings (Herring bodies) and reversible degeneration of neurosecretory axons following microiontophoretic ejection of vinblastine into the hypothalamo-neurohypophysial tract of the frog (Rana pipiens). Exp. Brain Res., in press.

Chauvet, M. T., J. Chauvet, and R. Acher (1975) The complete amino acid sequence of the major ovine neurophysin (MSELneurophysin); comparison with a re-investigated bovine MSEL-neurophysin. FEBS Lett. 58: 234-237.

Chauvet, M. T., J. Chauvet, and R. Acher (1976) The neurohypophysial hormone-binding proteins: Complete amino acid sequence of ovine and bovine MSEL-neurophysins. Eur. J. Biochem. 69: 475-485.

Coates, P. W., and E. C. Teh (1978) Demonstration of neurosecretory substance in previously scanned specimen. Adaptation of the Gomori-aldehyde fuchsin methods for correlative SEM/YEM/LM histochemistry. Am. J. Anat. 153: 469475.

Davis, B. J. (1964) Disc gel electrophoresis. Ann. N. Y. Acad. Sci. 121: 404-427.

Dean, C. R., M. D. Hollenberg, and D. B. Hope (1967) The relationship between neurophysin and the soluble proteins of pituitary neurosecretory granules. Biochem. J. 104: 8-10c.

Fink, D. J., J. T. Russell, and H. Gainer (1981) Multiple-rate components of axonally transported proteins in the hypothalamo-neurohypophysial system of the rat. J. Neurobiol. 12: $487-503$.

Gainer, H., Y. Sarne, and M. J. Brownstein (1977a) Biosynthesis and axonal transport of rat neurohypophysial proteins and peptides. J. Cell Biol. 73: 366-381.

Gainer, H., Y. Sarne, and M. J. Brownstein (1977b) Neurophysin biosynthesis: Conversion of a putative precursor during axonal transport. Science 199: 1354-1356.

Gainer, H., Y. P. Loh, and Y. Sarne (1977c) Biosynthesis of neuronal peptides. In Peptides in Neurobiology, H. Gainer, ed., pp 183-219, Plenum Press, New York.

Hammerschlag, R., A. R. Dravid, and A. Y. Chiu (1975) Mechanism of axonal transport: A proposed role for calcium ions. Science 188: 273-275.

Jones, C. W., and B. T. Pickering (1972) Intra-axonal transport and turnover of neurohypophysial hormones in the rat. J. Physiol. (Lond.) 227: 553-565.

Jones, C. W., R. E. Peter, and B. T. Pickering (1973) Intraneuronal transport in the hypothalamo-neurohypophysial system of the goldfish (Carassium auratus). Gen. Comp. Endocrinol. 20: 99-107.
Kent, C., and M. A. Williams (1974) The nature of hypothalamo-neurohypophysial neurosecretion in the rat. A study by light and electron microscope autoradiography. J. Cell. Biol. 60: $554-570$.

Laemmli, U. K. (1970) Cleavage of structural proteins during the assembly of the head of bacteriophage T4. Nature 227: $680-685$.

Land, H., G. Schutz, H. Schmale, and D. Richter (1982) Nucleotide sequence of cloned cDNA encoding bovine arginine vasopressin-neurophysin II precursor. Nature 295: 299-303.

Lasek, R., H. Gainer, and R. J. Pryzbylski (1974) Transfer of newly synthesized proteins from Schwann cells to squid giant axon. Proc. Natl. Acad. Sci. U. S. A. 71: 1188-1198.

Moens, L. (1972) Isolation of neurohypophysial hormones of Rana temporaria. Nature New Biol. 237: 268-269.

Moens, L. (1974) Isolation of neurointermediate pituitary proteins of the frog (Rana temporaria) and their tentative identification as neurophysin. Gen. Comp. Endocrinol. 22: 70-76.

Nishioka, R. S., D. Zambrano, and H. A. Bern (1970) Electron microscope radioautography of amino acid incorporation by supraoptic neurons of the rat. Gen. Comp. Endocrinol. 15: $477-483$.

Ochs, S. (1982) Axoplasmic Transport and Its Relation to Other Nerve Functions, pp. 35-45, John Wiley \& Sons, New York.

O'Farrell, P. (1975) High resolution two-dimensional electrophoresis of proteins. J. Biol. Chem. 250: 4007-4021.

Peek, J. C., and W. B. Watkins (1971) Identification of three neurophysin-like proteins from the chicken posterior pituitary gland. J. Endocrinol. 72: 5-6.

Pickering, B. T. (1968) A neurophysin from cod (Gadus morrhua) pituitary gland. Isolation and properties. J. Endocrinol. 42: 143-152.

Pickering, B. T., and C. W. Jones (1978) The neurophysins. In Hormonal Proteins and Peptides, C. H. Li, ed. pp. 104-158, Academic Press, New York.

Pickering, B. T., C. W. Jones, G. D. Burford, M. McPherson; R. W. Swann, P. E. Heap, and J. F. Morris (1975) The role of neurophysin proteins: Suggestions from the study of their transport and turnover. Ann. N. Y. Acad. Sci. 248: 15-35.

Russell, J. T., M. J. Brownstein, and H. Gainer (1979) Trypsin liberates an arginine vasopressin-like peptide and neurophysin from a $M_{\mathrm{r}} 20,000$ putative common precursor. Proc. Natl. Acad. Sci. U. S. A. 76: 6086-6090.

Russell, J. T., M. .J. Rrownstein, and H. Gainer (1980) Biosynthesis of vasopressin, oxytocin and neurophysins: Isolation and characterization of two common precursors. Endocrinology 107: 1880-1891.

Sachs, H. (1960) Vasopressin biosynthesis. I. In vivo studies. J. Neurochem. 5: 297-303.

Sachs, H. (1969) Neurosecretion. Adv. Enzymol. 32: 327-372.

Sachs, H., and Y. Takabatake (1964) Evidence for a precursor in vasopressin biosynthesis. Endocrinology 75: 943-948.

Sachs, H., P. Fawcett, Y. Takabatake, and R. Portanova (1969) Biosynthesis and release of vasopressin and neurophysin. Recent Prog. Horm. Res. 25: 447-491.

Sawyer, W. H. (1961) Neurohypophysial hormones. Pharmacol. Rev. 13: 225-277.

Schlesinger, D. H., B. T. Pickering, W. B. Watkins, J. C. Peek, L. G. Moore, T. K. Audhya, and X. Walter (1977) A comparative study of partial neurophysin protein sequences of cod, guinea pig, rat and sheep. FEBS Lett. 80: 371-373.

Seif, S. H., and A. G. Robinson (1978) Localization and release of neurophysins. Annu. Rev. Physiol. 40: 345-376.

Sloper, J. C. (1966) The experimental and cytological investigation of neurosecretion in the hypothalamus and pituitary. In The Pituitary Gland, G. W. Harris and B. 'T. Donovan, eds., pp. 131-239, Butterworth, London.

Swann, R. W., and B. T. Pickering (1976) Incorporation of 
radioactive precursors into the membrane and contents of the neurosecretory granules of the rat neurohypophysis as a method of studying their fate. J. Endocrinol. 68: 95-108.

Takaćs, B. (1979) Electrophoresis of proteins in polyacrylamide slab gels. In Immunological Methods, I. Lefkovits and B. Pernis, eds., pp. 81-105, Academic Press, New York.

Takabatake, Y., and H. Sachs (1964) Vasopressin biosynthesis. III. In vitro studies. Endocrinology 75: 934-942.

Vandesande, F., and K. Dierickx (1975) Identification of the vasopressin producing and of the oxytocin producing neurons in the hypothalamic magnocellular neurosecretory system of the rat. Cell Tissue Res. 164: 153-162.

Vandesande, F., and K. Dierickx (1976a) Immunocytochemical demonstration of the inability of the homozygous Brattleboro rat to synthesize vasopressin and vasopressin-associated neurophysin. Cell Tissue Res. 165: 307-316.

Vandesande, F., and K. Dierickx (1976b) Immunocytochemical demonstration of separate vasotocinergic and mesotocinergic neurons in the amphibian hypothalamic magnocellular neurosecretory system. Cell Tissue Res. 175: 289-296.

Vandesande, F., K. Dierickx, and J. De Mey (1975) Identification of the vasopressin-neurophysin II and the oxytocinneurophysin I producing neurons in the bovine hypothalamus. Cell Tissue Res. 156: 189-200.

Van Dyke, H. B., B. F. Chow, R. O. Greep, and A. Rothen (1942) The isolation of a protein from the pars neuralis of the ox pituitary with constant oxytocic-pressor and diuresisinhibiting effects. J. Pharmacol. Exp. Ther. 74: 190-209.

Watkins, W. B. (1975) Immunocytochemical identification of neurophysin-secreting neurons in the hypothalamo-neurohypophysial system of some non-mammalian vertebrates. Cell Tissue Res. 162: 511-521.

Wu, T. C., and S. E. Crumm (1976) Amino acid sequence of bovine neurophysin II: A re-investigation. Biochem. Biophys. Res. Commun. 68: 634-639. 